\title{
Strategi guru dalam membangun kedisiplinan belajar siswa kelas III di Madrasah Ibtidaiyah DDI Ainus Syamsi Kota Makassar
}

\author{
FITRIAWAN
}

17210010

STAI DDI KOTA MAKASSAR

$\underline{\text { Fitriawan150490@gmail.com }}$

\begin{abstract}
Abstrak
Disiplin berarti tertib, taat atau mengendalikan tingkah laku karakter ini perlu ditanamkan pada anak, agar anak tersebut biasa mengendalikan tingkah lakunya dan dapat , mematuhi tata tertib yang ada. Selain itu dengan pembentukan karakter pada diri anak juga merupakan salah satu tujuan dari pendidikan. Dengan adanya disiplin kegiatan belajar mengajar akan berlangsung dengan baik dan karakter disiplin ini akan dibawa hingga siswa besar. Rumusan masalah pada penelitian ini bertujuan untuk mengetahui bagaimana strategi guru dalam membangun kedisiplinan belajar pada siswa kelas III MI DDI Ainus Syamsi Kota Makassar dan bagaimana pelaksanaan strategi guru dalam membentuk sikap disiplin pada siswa kelas III MI DDI Ainus Syamsi Kota Makassar. Untuk maencapai tujuan tersebut, digunakan pendekatan kualitatif dan teknik pengumpulan data yang digunakan adalah observasi, wawancara, dan dokumentasi. Data dianalisis dengan cara mengumpulkan data, menganalisa data, kemudian penarikan kesimpulan. Hasil penelitian menunjukkan bahwa, (1) Strategi guru dalam membangun kedisiplinan siswa kelas III MI DDI Ainus Syamsi dimulai dengan diadakan berbagai fasilitas yang diperlukan di dalam ruang kelas agar siswa terbiasa berprilakudisiplin. (2) Pelaksanaan strategi guru dalam membentuk sikap disiplin melalui pembelajaran yaitu dengan menggunakan keteladanan yaitu memberikan contoh keteladanan yang baik kepada siswa, dan pemberian sanksi yang mendidik, serta memberikan reward bagi siswa yang berprestasi dan tidak melanggar tata tertib di sekolah dan tata tertib kelas secara kualitatif sudah menunjukkan hasil dari proses pembelajaran melalui strategi pusat belajar dengan model yang diberikan guru.
\end{abstract}

\section{Kata Kunci: Strategi Guru, Kedisiplinan Belajar}




\section{PENDAHULUAN}

Peserta didik merupakan bagian dari globalisasi maka sangat penting menjaga karakter dari peserta didik, agar peserta didik mampu mengikuti perubahan zaman dengan tetap memegang karakter sesuai dengan identitas bangsa. Jika peserta didik mempunyai karakter yang rapuh, mudah diterjang ombak, terjerumus dalam tren budaya yang tidak sesuai, dan memikirkan akibat yang ditimbulkan. Prinsip-prinsip moral, budaya bangsa, dan perjuangan hilang dari karakteristikpeserta didik. Inilah yang menyebabkan dekadensi moral serta hilangnya kreatifitas dan produktifitas bangsa. Sebab ketika karakter suatu bangsa rapuh maka ciri khas dari bangsa tersebut akan hilang dan akan mudah terjerumus dengan globalisasi. Oleh karna itu perlu diterapkan nilai-nilai kedisiplinan didalam semua lembaga pendidikan sebagai social control yang diharapkan.

Kedisiplinan ini berasal dari kata disiplin, sedangkan istilah bahasa inggrisnya yaitu discipline yang berarti 1) Tertib, taat atau mengendalikan tingkah laku, penguasaan diri 2) Latihan membentuk, meluruskan atau menyempurnakan sesuatu, sebagai kemampuan mental dan karakter moral 3) Hukuman yang diberikan untukmelatih dan memperbaiki 4) Kumpulan atau system-sistem peraturan-peraturan bagi tingkah laku. Seorang peserta didik perlu memiliki karakter disiplin dengan melakukan latihan untuk memperkuat dirinya sendiri untuk selalu terbiasa patuh dan dapat mrngendalikan dirinya. Sikap disiplin yang timbul pada peserta didik atas kesadaran dirinya sendiri bukan karna orang lain ataupun karna paksaan dari hukuman. Oleh karna itu, penting bagi guru untuk mengetahui strategi apa yang digunakan untuk menanamkan karakter disiplin pada siswa, dan untuk mengetahui apa saja factor dan

penghambat dalam membentuk karakter disiplin siswa kelas III MI DDI Ainus Syamsi Kota Makassar. 


\section{Strategi guru dalam membentuk sikap disiplin melalui pembelajaran pada siswa kelas III MI DDI Ainus Syamsi Kota Makassar}

Strategi guru dalam membentuk sikap disiplin siswa didalam pembelajaran ini adalah dengan:

a. Keteladanan

Melalui keteladanan yang ditunjukkan oleh pendidik di MI DDI Ainus Syamsi dengan selalu datang tepat waktu merupakan salah satu strategi yang dilakukan di sekolah tersebut sehingga siswa pun selalu datang tepat waktu. Patut bagi kita untuk merenungkan dan merespon diri tentang betapa pentingnya penghormatan dalam pemakaian dan manajemen waktu, agar tidak termasuk kelompok orang-orang yang merugi.

b. Pemberian Reward (hadiah)

Penghargaan adalah salah satu dari kebutuhan pokok yang mendorong seseorang untuk mengaktualisasikan dirinya. Penghargaan adalah unsur disiplin yang sangat penting dalam pengembangan diri dan tingkah laku anak. Seorang akan terus berupaya meningkatkan dan mempertahankan disiplin apabila pelaksanaan disiplin itu menghasilkan prestasi dan produktivitas yang kemudian mendapat penghargaan.

c. Pemberian Sanksi

Hukuman adalah salah satu strategi yang digunakan oleh pendidik berupa sanksi yang bersifat pedagogic atau mendidik, dengan mempertimbangkan pelanggaran yang dilakukan oleh siswa serta akibat-akibat yang kemungkinan ditimbulkan melalui hukuman yang diberikan oleh pendidik. Seorang penidik dilarang memberikan hukuman yang menimbulkan rasa sakit pada siswa secara fisik dan psikis.

d. Buku Penghubung

Buku penghubung merupakan buku yang berisi tata tertib yang diberlakukan jika seorang siswa melakukan pelanggaran aturan tata tertib 
di sekolah. Penerapan strategi dengan buku penghubung ini menggunakan sisrem point, dimana setiap pelanggaran yang dilakukan oleh siswa diberikan sanksi point pada masing-masing aturan.

e. Buku Prestasi Mengaji dan Menghafal

Buku prestasi yang diberikan pada setiap peserta didik adalah untuk mengetahui dan mengontrol sweberapa jauh tingkat pencapaian yang dicapai setiap peserta didik dalam sepekan dan akan dievaluasi setiap akhir bulan.

\section{Pelaksanaan strategi guru dalam Membentuk Sikap Disiplin Melalui Pe,belajaran Pada Siswa Kelas III MI DDI Ainus Syamsi Kota Makassar}

Dalam pembentukan karakter disiplin pada siswa diperlukan strategi agar pembentukan karakter berhasil, di bawah ini beberapa strategi yang ditemukan peneliti dari hasil penelitian di lapangan:

1. Guru menggunakan strategi keteladanan, keteladanan yang dicontohkan para guru akan menjadi contoh bagi siswanya. Keteladanan yang dicontohkan ketika guru datang tepat waktu datang ke sekolah sebelum jam 07.00, memakai seragam sesuai dengan jadwal yang ditentukan. Keteladanan merupakan hal utama karna siswa akan melihat dan menirusemua hal yang dilakukan oleh guru. Meskipun ditemukan ada juga guru yang tidak tepat waktu.

2. Melalui pembiasaan guru membiasakan siswanya datang ke sekolah sebelum jam 07.00, meminta ijin apabila ingin keluar kelas, mengucapkan salam ketika masuk ruang kelas, doa bersama sebelum memulai dan mengakhiri pembelajaran.

3. Guru sebagai model atau contoh yang utama jika di sekolah. Siswa menganggap guru yang paling benar, apabila guru kelas lebih banyak bertemu dengan siswa ketika berada di dalam kelas maupun di luar kelas, 
jika gurunya menyenangkan siswa akan merasa nyaman. Terdapat empat elemen penting yang harus diperhatikan dalam pembelajaran melalui pengamatan: perhatian (atensi), mengingat (retensi), Pembentukan (production), dan motivasi (motivation). Tahap pertama yang dilakukan oleh guru dalam membentuk karakter disiplin dengan memberikan perhatian (attention).

4. Pemberian Reward (hadiah)

Setiap siswa yang melaksanakan aturan yang berlakudisekolah maka guru akan memberikan reward (hadiah) kepada siswa yang bersangkutan baik berupa pujian, reward bintang ataupun reward langsung berupa barang.

5. Pemberian sanksi

Strategi yang digunakan guru dalam membentuk karakter disiplin siswa melalui pemberian sanksi, pemberian sanksi juga disini dibutuhkan. Pemberian sanksi diberikan ketika anak melanggar peraturan atau tata tertib yang sudah ada. Peserta didik tidak langsung diberikan hukuman akan tetapi ada tahapan-tahapan pelanggaran sebelum memberi hukuman, sebelumnya aka nada teguran sebelum pemberian sanksi/hukuman. Dalam pemberian sanksi disini dengan unsur mendidik. Dengan tujuan agar siswa mempunyai arah untuk tidak berbuat hal-hal yang tidak baikyang menyimpang dari karakter disiplinyang diajarkan oleh guru di sekolah.

\section{KESIMPULAN}

Berdasarkan hasil pembahasan dan analisis dalam penelitian ini, diperoleh kesimpulan:

1. Strategi yang digunakan dalam pembinaan sikap disiplin ada peserta didik yaitu:
a. Keteladanan
b. Hukuman dan Reward
c. Buku Penghubung 

d. Buku Kontrol Mengaji dan Menghafal

2. Cara menerapkan strategi dalam pembinaan sikap disiplin belajar pada peserta didik yaitu:
a. Hadir tepat waktu
b. Mengucapakan salam ketika masuk ke ruang kelas
c. Doa bersama sebelum memulai dan mengakhiri pembelajaran
d. Pemberian reward ketika anak didik berprestasi atau mematuhi tata tertib di sekolah dan pemberian sanksi ketika anak melanggar peraturan atau tata tertib yang sudah ada.

\section{DAFTAR PUSTAKA}

Arsyam, M, Mujaddidah Alwi, (2020). Manajemen Hidup Dalam Prespektif Al- Qur'an.

Fitri,Agus Zainal, Pendidikan Karakter Berbasis Nilai \& Etika di Sekolah, (Yogyakarta: Ar Ruzz Media 2012)

Ghorbani Somayeh,dkk,Investigation the Effect of Pocitif Disipline on the Learning Process and its Achieving Strategies with Focusing on the Students Abilities, International Journal of Academic Research in Business and Social Sciences, Vol.3, No, 5, tahun 2013

Herianto, h. (2020). Teknik Menulis Artikel Konseptual. 
Kamila Zulfa maulidia, Penanaman Karakter Disiplin dan tanggung jawab siswa kelas $\quad X \quad$ Melaui Pembelajaran PAI (Yogyakarta, Skripsi Universitas Islam Negri Sunan Kalijaga, 2013)

Ngalim Purwanto, Psikologi Pendidikan, Bandung: Remaja osdakarya, 2014

Prasetyo Andre, Pengaruh konsep Diri dan kedisiplinan terhadap prestasibelajar siswa jurusan teknik Audio di SMK Muhammadiyah 3 yogyakarta

Siska Yuliantika, "Analisis Faktor-faktor yang Mempengaruhi disiplin belajar Siswa Kelas X, XI, Dan XII di SMA Bhakti Yasa SINgaraja Tahun Pelajaran 2016/2017”, Journal Jurusan Pendidikan Ekonomi, Vol. 9, No.1, Tahun 2017

Suyono dan Haryanto, Belajar dan Pembelajaran Teori dan Konsep Dasar (Bandung: Rosda Karya, 2014)

Tim Penyusunan, Kamus Bahasa Indonesia (Bandung: Pusat Bahasa, 2018)

Wuryandani wuri, dll. Internalisasi Nilai Karakter Disiplin Melalui Penciptaan Iklim Kelas yang Kondusif di $\quad S D$ Muhammadiyah Sopen Yogyakarta (Jurnal, Tahun IV, Nomor 2, Juni 2014) 
